\title{
Hypnose - underholdning eller behandling?
}

Hypnose ble benyttet ved kirurgiske inngrep allerede på 1800tallet, men først rundt 1950 begynte man å utvikle kunnskap om terapeutiske intervensjonsmetoder $(1,2)$. Hypnose kan enkelt beskrives som en naturlig forekommende tilstand der kroppen er avslappet mens bevisstheten er oppmerksom og fokusert. En vanlig misforståelse er at hypnose er en form for bevisstløshet som likner på søvn. Nyere forskning tilsier imidlertid at hypnose snarere er en tilstand med skjerpet oppmerksomhet og økt suggestibilitet, dvs. mottakelighet for det som sies og skjer der og da $(1,2)$. Dette er en naturlig tilstand, for eksempel når barn er engasjert i lek eller ser film. En tilsvarende fokusert oppmerksomhet preger ofte pasienten i første møte med legen (3). Hypnoterapi er en behandlingsmodalitet med spesifikke terapeutiske mål benyttet mens pasienten er $i$ en hypnotisk tilstand $(1,2)$. En klinisk hypnoterapeutisk sesjon kan skjematisk deles inn i seks faser: introduksjon, induksjon, fordypning, posthypnotisk (terapeutisk) suggesjon, tilbakebringing av pasienten til her-og-nå-situasjonen og tilbakemelding.

Ved bruk av hypnose er det viktig at den kliniske tilnærmingen er individuelt tilpasset pasientens ønsker og behov. Metoden er derfor mindre egnet for dobbeltblinde fors $ø \mathrm{k}$, og publiserte arbeider er fortsatt ofte basert på kasuistikker (4). Hypnoterapi er godt egnet til å understøtte kognitiv atferdsterapi og psykoterapi ved bl.a. depresjon, angst, smerter og traumer $(1,2,4)$, men fagområdet er i dag for lite kjent blant helsepersonell. Det er godt dokumentert at bruk av avspenningsteknikker, forestillingsbilder og hensiktsmessig bruk av ord kan bidra til å forebygge sprøyteskrekk og andre posttraumatiske reaksjoner etter kliniske undersøkelser og invasive prosedyrer hos barn (2). Studier viser at opplæring i selvhypnose kan redusere, eventuelt helbrede, både plager og symptomer ved tilstander som astma, migrene, enuresis nocturna (5) og irritabel tarm (6). I internasjonale retningslinjer anbefales hypnoterapi for utvalgte pasienter ved for eksempel irritabel tarm-syndrom (7). En randomisert, kontrollert studie hos barn med magesmerter viser tilsvarende gode effekter som hos voksne (8). Nå er det også bedre muligheter for objektiv registrering av endring av f.eks. pasientens hjertefrekvens og hudtemperatur ved terapeutiske intervensjoner (2). I tillegg foreligger studier som inkluderer bl.a. funksjonell MR, noe som kan bidra til å forstå hva som skjer i hjernen ved hypnotiske suggesjoner $(9,10)$. Det er behov for flere randomiserte, kontrollerte studier av hypnose med god nok metodikk og styrke til å vise effekt på pasientviktige utfall.

Hypnose og hypnoterapi kan også ha negative effekter. Forbud mot bruk av hypnose i underholdningsøyemed har nettopp vært begrunnet ut fra den skam/ydmykelse, ev. retraumatisering som personer som primært samtykket til å stille opp for hypnotisøren, senere har lidd under (11). Det er derfor viktig at den som praktiserer ferdighetene gjør det med tilstrekkelig kompetanse og innen en profesjonsetisk ramme.

Justisdepartementets straffelovskommisjon har foreslått å oppheve $\S 364$ i straffeloven som sier at bare leger, psykologer og tannleger kan praktisere hypnose. Lovforslaget er nå sju år etter ikke ferdigbehandlet, så paragrafen er fremdeles gjeldende. Det er viktig at klinikere som skal bruke hypnose i praksis, har fått profesjonell opplæring og veiledning $(1,2)$. Innsikt i pasient-lege-forholdet, oppmerksomt nærvær, klinisk kommunikasjon og vurdering av pasientens motivasjon for endring inngår i opplæringen i ulike former for terapi, bl.a. kognitiv atferdsterapi. Likevel er det min erfaring at kunnskap om hvordan fokusert oppmerksomhet, suggestibilitet og hypnoterapi kan understøtte behandling, ofte gir aha-opplevelser og nye terapeutiske muligheter for deltakere i utdanning i klinisk hypnose.

Det er ingen tvil om at vi trenger mer forskning på hypnoterapi, både i form av randomiserte studier og kvalitative studier. Den kunnskapen vi allerede har, støtter imidlertid min kliniske erfaring med at vi er langt unna å ha et adekvat tilbud til våre pasienter.

Inger Helene Vandvik

i.h.vandvik@medisin.uio.no

Slependen

Inger Helene Vandvik (f. 1938) er tidligere avdelingsoverlege ved Barneog ungdomspsykiatrisk seksjon, Rikshospitalet og professor ved Universitetet i Oslo. Hun har i fire år ledet klinisk utdanning i hypnose-hypnoterapi med fokus på barn, ungdom og familier på regionsenteret for barn og unges psykiske helse i $\varnothing \varnothing$ - $\varnothing$ st.

Forfatter har fylt ut ICMJE-skjemaet og oppgir følgende interessekonflikt: Hun har mottatt forelesningshonorar fra Norsk Forening for Klinisk Evidensbasert Hypnose.

\section{Litteratur}

1. Nash MR, Barnier AJ, red. The Oxford handbook of hypnosis theory, research and practice. Oxford: Oxford University Press, 2008.

2. Kohen DP, Olness K. Hypnosis and hypnotherapy with children. 4. utg. New York, NY: Routledge, 2011

3. Ewin DM. 101 things I wish I'd known when I started using hypnosis. Wales: Crown House Publishing, 2009: 1-16.

4. Huynh ME, Vandvik IH, Diseth TH. Hypnotherapy in child psychiatry: the state of the art. Clin Child Psychol Psychiatry 2008; 13: 377-93.

5. Diseth TH, Vandvik IH. Hypnoterapi ved behandlingsrefraktær enuresis nocturna. Tidsskr Nor Lægeforen 2004: 124: 488-91.

6. Vlieger AM, Menko-Frankenhuis C, Wolfkamp SC et al. Hypnotherapy for child ren with functional abdominal pain or irritable bowel syndrome: a randomized controlled trial. Gastroenterology 2007; 133: 1430-6.

7. Spiller R, Aziz Q, Creed F et al.. Guidelines on the irritable bowel syndrome: mechanisms and practical management. Gut 2007; 56: 1770-98.

8. Ford AC, Vandvik PO. Irritable bowel syndrome. Clin Evid [online] 2012; e-publisert 6.1.2012

9. Kihlstrom JF.Neuro-hypnotism: Prospects for hypnosis and neuroscience. Cortex 2012: e-publisert 5.6.2012.

10. Oakley DA, Halligan PW. Hypnotic suggestion and cognitive neuroscience. Trends Cogn Sci 2009; 13: 264-70.

11. Wain HJ, Dailey J. A dissosiative episode following stage hypnosis in a combatinjured soldier. Am J Clin Hypn 2010; 52: 183-8. 